\title{
Karakteristik dan Stabilitas Fisik Krim Amniotic Membrane Stem Cell Metabolite Product dengan Penambahan SPACE Peptide
}

Nisa Qurrota A'yun ${ }^{1}$, Tristiana Erawati ${ }^{1}{ }^{*}$, Cita Rosita Sigit Prakoeswo ${ }^{2,3}$, Widji Soeratri ${ }^{1}$

${ }^{1}$ Departemen Farmasetika, Fakultas Farmasi, Universitas Airlangga, Surabaya, Indonesia

${ }^{2}$ Departemen Kesehatan Kulit dan Kelamin, Fakultas Kedokteran, Universitas Airlangga, Surabaya, Indonesia

${ }^{3}$ Departemen Ilmu Kesehatan Kulit dan Kelamin, RSUD Dr. Soetomo, Surabaya, Indonesia

*Corresponding author: era_ffua@yahoo.co.id

Submitted: 17 Januari 2020

Accepted: 28 Januari 2020

Published: 25 Juni 2020

\begin{abstract}
Background: The use of growth factors in cosmetics is a promising effort in overcoming aging, and becomes a challenge for its use. Physical characteristics and stability are important parameters in the cosmetic preparations which contain growth factors because they can directly influence the effectiveness of antiaging efficacy. Objective: To evaluate the effect of the addition of SPACE peptide at different weight ratio to Amniotic Membrane Stem Cell Metabolite Product (AMSC-MP) $(F 1=1: 0 ; F 2=1: 1 ; \quad F 3=1: 2 ; \quad F 4=1: 3)$ on the characteristics and physical stability of the antiaging cream. Methods: The antiaging cream were firstly determined for organoleptic, $\mathrm{pH}$, and spredibility. Physical stability was evaluates for the antiaging cream during the preparation for 21 days of storage. Results: Cream preparations which contains AMSC-MP with SPACE peptide has characteristics; $p H$ range of 5.8 - 6.5 statistical test results showed a significant difference, the spread of the preparation between $5.6-7.2 \mathrm{~cm}$ test results with the Kruskal Wallis method showed no significant differences, a slight fishy odor, milky white color and soft texture. The results of the stability test on the $\mathrm{pH}$ value and the spreadability showed that the cream formula with the addition of various concentrations of SPACE pepide was stable for 21 days storage. Conclusion: The increased concentration of SPACE peptide increases the preparation $\mathrm{pH}$ but does not affect the spread, odor, color and texture of the preparation. All AMSC-MP cream preparation formulas with SPACE peptide were stable for 21 days of storage.
\end{abstract}

Keywords: AMSC-MP, cream, physical characteristic, physical stability, SPACE peptide

\begin{abstract}
Abstrak
Pendahuluan: Penggunaan growth factor dalam kosmetika adalah upaya yang menjanjikan dalam mengatasi masalah penuaan, namun juga menjadi sebuah tantangan tersendiri untuk pengaplikasiannya. Karakteristik dan stabilitas fisik merupakan parameter yang penting dalam formulasi sediaan, utamanya pada sediaan kosmetika yang mengandung growth factor karena dapat berpengaruh langsung terhadap efektifitas kandungan zat aktifnya. Tujuan: Mengevaluasi pengaruh perbandingan Amniotic Membran Stem Cell Metabolite Product (AMSC-MP) dan SPACE peptide ( $\mathrm{F} 1=1: 0 ; \mathrm{F} 2=1: 1 ; \mathrm{F} 3=1: 2 ; \mathrm{F} 4=1: 3$ ) terhadap karakteristik dan stabilitas fisik krim antiaging AMSC-MP yang mengandung growth factor. Metode: Uji karakteristik sediaan dievaluasi dengan parameter organoleptis, $\mathrm{pH}$ dan daya sebar. Uji stabilitas fisik dilakukan dengan mengevaluasi karakteristik sediaan selama 21 hari penyimpanan. Hasil: Sediaan krim yang mengandung AMSC-MP dengan SPACE peptide memiliki karakteristik; rentang pH 5,8 - 6,5 hasil uji statistik dengan metoda ANOVA satu arah menunjukan perbedaan bermakna, daya sebar sediaan antara 5,6 - 7,2 cm hasil uji dengan metoda Kruskal Wallis menunjukkan tidak ada perbedaan yang bermakna, bau sedikit amis, warna putih susu dan tekstur lembut. Hasil uji stabilitas terhadap nilai $\mathrm{pH}$ dan daya sebar menunjukkan bahwa formula krim dengan penambahan berbagai konsentrasi SPACE peptide stabil selama penyimpanan 21 hari. Kesimpulan: Peningkatan konsentrasi SPACE
\end{abstract}


peptide meningkatkan $\mathrm{pH}$ sediaaan namun tidak mempengaruhi daya sebar, bau, warna dan tektur sediaan. Semua formula sediaan krim AMSC-MP dengan SPACE peptide stabil selama 21 hari penyimpanan.

Kata kunci: AMSC-MP, karakteristik fisik, krim, SPACE peptide, stabilitas fisik

\section{PENDAHULUAN}

Penuaan adalah sebuah proses biologi kompleks yang merupakan konsekuensi dari pengaruh faktor intrinsik dan dapat dipercepat oleh faktor ekstrinsik. Paparan sinar UV merupakan faktor ekstrinsik utama penyebab terjadinya penuaan (Shin dkk., 2019). Gejala klinis yang terjadi pada penuaan adalah timbulnya kerutan-kerutan (wrinkle), perubahan warna kulit, perubahan tekstur serta berkurangnya elastisitas. Terapi yang bisa digunakan untuk mengatasi permasalahan tersebut salah satunya adalah penggunaan kosmetika antiaging yang, mengandung metabolit stem cell (Lee dkk., 2014).

Amniotic Membran Stem Cell Metabolit Product (AMSC-MP) adalah produk metabolit dari stem cell yang diambil dari membran amnion (Prakoeswo dkk., 2018). Produk metabolit mempunyai keuntungan mengandung komposisi growth factor yang sama dengan stem cell-nya, serta lebih mudah dibuat karena tidak memerlukan bahan pembawa tertentu untuk mempertahankan stem cell tetap hidup (Seo dkk., 2013). Atas dasar potensi AMSC-MP tersebut pada penelitian ini memformulasikan AMSC-MP menjadi kosmetika antiaging dalam bentuk sediaan krim.

Untuk memformulasikan AMSC-MP menjadi bentuk sediaan krim mempunyai permasalahan karena ukuran molekul rata-rata growth factor lebih dari $20 \mathrm{kDa}$, sementara ukuran molekul yang dapat terpenetrasi ke dalam kulit maksimal adalah $500 \mathrm{Da}$ (Bos \& Meinardi, 2000). Sehingga perlu penambahan enhancer yang dapat memfasilitasi AMSC-MP melewati stratum korneum agar dapat menghasilkan efek yang diharapkan. Penelitian terbaru menemukan sebuah alternatif untuk membantu penetrasi suatu makromolekul ke dalam stratum corneum secara non invasif tanpa menimbulkan efek iritasi pada kulit yaitu dengan menggunakan skin penetrating peptide enhancer (SPPs) salah satu contohnya adalah SPACE peptide. Pada penelitian in vitro dan in vivo membuktikan bahwa ketika SPACE peptide dikonjugasikan secara langsung dengan siRNA yang mempunyai ukuran molekul > $300 \mathrm{kDa}$, meningkatkan absorbsi ke dalam kulit dengan cara berinteraksi dengan struktur sekunder protein kulit (Hsu \&
Mitragotri, 2011). Sementara mekanisme kerja SPACE peptide yang diteliti oleh Kumar dkk. (2015) terbukti dalam bentuk tunggal mempunyai kemampuan meningkatkan afinitas terhadap keratin dan korneosit melalui jalur transeluler sehingga memfasilitasi makromolekul menembus stratum korneum ke dalam epidermis dan dermis. SPACE peptide diketahui memiliki toksisitas yang paling redah dibandingkan dengan peptide yang lain (Kumar dkk., 2015). Berdasarkan beberapa penelitian tersebut, menjadi dasar pemilihan SPACE peptide sebagai enhancer untuk mefasilitasi AMSC-MP masuk ke dalam stratum korneum. Penelitian ini untuk mengevaluasi pengaruh penambahan konsentrasi SPACE peptide terhadap karakteristik dan stabilitas fisik krim antiaging AMSCMP. Perbandingan konsentrasi AMSC-MP:SPACE peptide pada Formula 1(F1), Formula 2 (F2), Formula 3 (F3) dan Formula 4 (F4) berturut turut adalah 1:0; $1: 1 ; 1: 2 ; 1: 3$.

\section{BAHAN DAN METODE Bahan}

Bahan-bahan yang digunakan dalam penelitian ini memiliki derajat farmasetis kecuali dinyatakan lain; AMSC-MP (dikultur di Bank Jaringan dan Pusat Biomaterial RSUD Dr. Soetomo), SPACE Peptide (diimpor dari Medchem Express), asam strearat, setil alkohol, liquid paraffin, gliserin, propilenglikol, fenoxyethanol, aquadest, dan air bebas $\mathrm{CO}_{2}$.

\section{Alat}

Alat-alat yang digunakan adalah $\mathrm{pH}$ meter (merk SCHOTT CG 842), alat uji daya sebar (Lab.Farmasetika Universitas Airlangga), stirrer, cawan porselen, alat-alat gelas, waterbath dan pot krim.

\section{Metode}

\section{Pembuatan formula krim}

Komponen penyusun formula krim dapat dilihat pada Tabel 1. Semua bahan ditimbang terlebih dahulu. Fase Minyak (asam stearat, setil alkohol, paraffin liquid), dipanaskan $\mathrm{di}$ atas waterbath hingga temperatur $70^{\circ} \mathrm{C}$ (campuran pertama). Fase air (gliserin, propilenglikol, fenoxietanol) dicampur menjadi satu di dalam gelas beker dan dipanaskan 
sampai suhu kurang lebih $75^{\circ} \mathrm{C}$ (campuran kedua). Campuran kedua (fase air) sedikit demi sedikit dimasukkan ke dalam campuran pertama (fase minyak) kemudiaan dihomogenkan dengan stirrer dengan kecepatan $250 \mathrm{rpm}$ selama 20 menit. Selanjutnya campuran diturunkan, diaduk sampai terbentuk masa krim yang baik. Setelah kurang lebih 30 menit sampai suhu dibawah $40^{\circ} \mathrm{C}$, dimasukkan campuran AMSC-MP dengan SPACE Peptide pada perbanding masingmasing kelompok F1(1:0), F2(1:1), F3(1:2) dan F4(1:3), kemudian diaduk hingga homogen.

Tabel 1. Formula sediaan krim freeze dried AMSC-MP dengan variasi konsentrasi SPACE peptide

\begin{tabular}{cccccc}
\hline \multirow{2}{*}{ Fungsi } & \multirow{2}{*}{ Bahan } & F1 & F2 & F3 & F4 \\
\cline { 3 - 6 } & & 0,008 & 0,008 & 0,008 & 0,008 \\
Bahan aktif & AMSC-MP & 0 & 0,008 & 0,016 & 0,024 \\
Enhancher & SPACE peptide & 10 & 10 & 10 & 10 \\
& Asam stearat & 6 & 6 & 6 & 6 \\
Fase minyak & Setil alkohol & 6,6 & 6,6 & 6,6 & 6,6 \\
& Liquid paraffin & 5 & 5 & 5 & 5 \\
& Glyserin & 30 & 30 & 30 & 30 \\
Fase air & Propilen glycol & 30 & 0,1 & 0,1 & 0,1 \\
\hline & Phenoxyethanol & 0,1 & \multicolumn{3}{c}{ Ad 100} \\
\hline
\end{tabular}

\section{Penentuan karakteristik dan stabilitas fisik sediaan krim antiaging AMSC-MP}

Uji karakteristik sediaan krim antiaging AMSCMP meliputi pengamatan organoleptis, pemeriksaan $\mathrm{pH}$ dan pengujian daya sebar yang dilakukan setelah pembuatan sediaan. Sedangkan pada uji stabilitas fisik dilakukan terhadap sediaan selama penyimpanan 21 hari meliputi pengujian $\mathrm{pH}$ dan daya sebar pada suhu ruang $30 \pm 0,5^{\circ} \mathrm{C}$ dan $\mathrm{RH} 70 \pm 2 \%$. Kondisi penyimpanan terhindar dari sinar matahari.

\section{Uji organoleptis}

Pengujian organoleptis meliputi homogenitas, tekstur, warna, dan bau dari krim AMSC-MP.

\section{Pengukuran pH sediaan}

Pengukuran karakteristik $\mathrm{pH}$ sediaan dilakukan dengan cara mengencerkan sampel dengan air bebas $\mathrm{CO}_{2}$ menggunakan perbandingan 1:9. Sampel yang telah diencerkan diuukur pHnya menggunakan $\mathrm{pH}$ meter digital merk SCHOTT CG 842.

\section{Uji daya sebar sediaan}

Pengujian daya sebar dilakukan dengan cara menimbang 0,5 gram sampel kemudian diletakkan diantara 2 plat kaca yang salah satunya berskala. Krim dibiarkan menyebar selama 1 menit, kemudian diukur diameternya. Selanjutnya dilakukan penambahan beban yang semakin meningkat dengan kelipatan 5 gram. Setiap 1 menit setelah penambahan beban, dicatat diameternya, sampai didapatkan diameter yang konstan sehingga cukup untuk mengevaluasi pengaruh beban terhadap daya sebarnya (Metasari, 2006).

\section{HASIL DAN PEMBAHASAN}

\section{Hasil pemeriksaan organoleptis}

AMSC-MP dalam bentuk freeze dried adalah serbuk berwarna putih tulang dengan bau sedikit amis. Sedangkan SPACE peptide berbentuk serbuk berwarna putih dan tidak berbau. Dari uji organoleptis krim, masing-masing formula memberikan hasil yang relatif sama yaitu warna putih susu, bau khas sedikit amis, konsistensi semi solid dan bertekstur lembut.

\section{Hasil pemeriksaan karakteristik pH}

Hasil pemeriksaan $\mathrm{pH}$ sediaan dapat dilihat pada Tabel 2 dan Gambar 1. Nilai $\mathrm{pH}$ rata-rata semua formula masuk ke dalam rentang $\mathrm{pH}$ normal kulit yaitu 4,5 - 6,8 (Lambers dkk., 2006). Peningkatan konsentrasi SPACE peptide diikuti dengan peningkatan nilai $\mathrm{pH}$ sediaan. Selanjutnya dilakukan uji normalitas terhadap data $\mathrm{pH}$ masing-masing formula. Berdasarkan uji normalitas diketahui bahwa data bersifat parametrik, sehingga dilanjutkan menggunakan uji One Way ANOVA. Hasil uji One Way ANOVA menunjukkan terdapat perbedaan bermakna pada nilai $\mathrm{pH}$ antar formula $(\mathrm{p}<0,05)$. Untuk mengetahui kelompok mana yang berbeda bermakna dilakukan uji Post Hoc Tuke. Dari hasil pengujian Post Hoc Tukey, diketahui bahwa formula yang berbeda bermakna adalah F4 dengan semua formula lain. Sedangkan F3 tidak berbeda bermakna dengan F2 namun berbeda bermakna dengan F1, sementara F1 tidak berbeda bermakna dengan F2. Sehingga disimpulkan bahwa penambahan konsentrasi SPACE peptide meningkatkan $\mathrm{pH}$ sediaan. 
Tabel 2. Hasil pemeriksaan karakteristik nilai pH formula 1 (F1), formula 2 (F2), formula 3 (F3) dan formula 4 (F4)

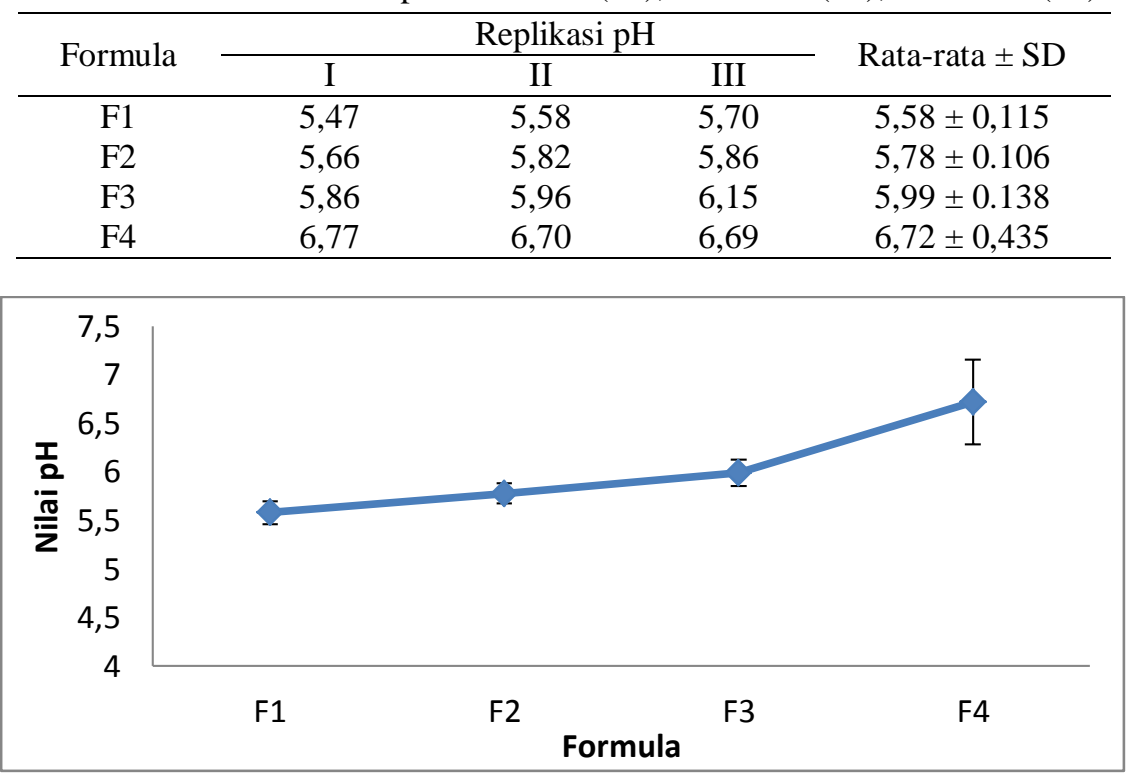

Gambar 1. Grafik profil karakteristik nilai pH formula 1 (F1), formula 2 (F2), formula 3 (F3) dan formula 4 (F4)

SPACE peptide mempengaruhi nilai $\mathrm{pH}$ sediaan karena berdasarkan hasil pengujian mempunyai nilai pH 7,2, akibatnya semakin besar konsentrasinya menyebabkan terjadinya peningkatan nilai $\mathrm{pH}$ sediaan. Akan tetapi semua sediaan masih memenuhi rentang pH normal kulit (4,5 - 6,8) (Lambers dkk., 2006) sehingga meminimalkan risiko iritasi pada penggunaan topikal.

Tabel 3. Hasil pengukuran daya sebar formula 1 (F1), formula 2 (F2), formula 3 (F3), dan formula 4 (F4)

\begin{tabular}{|c|c|c|c|c|c|}
\hline \multirow{2}{*}{ Formula } & \multirow{2}{*}{$\begin{array}{l}\text { Beban } \\
\text { (gram) }\end{array}$} & \multicolumn{3}{|c|}{ Diameter daya sebar $(\mathrm{cm})$} & \multirow[t]{2}{*}{ Diameter rata-rata $(\mathrm{cm})$} \\
\hline & & I & II & III & \\
\hline \multirow{6}{*}{$\mathrm{F} 1$} & - & 5,40 & 5,50 & 5,40 & $5,43 \pm 0,06$ \\
\hline & 5 & 5,50 & 5,70 & 5,60 & $5,60 \pm 0,10$ \\
\hline & 10 & 5,60 & 5,80 & 5,80 & $5,73 \pm 0,11$ \\
\hline & 15 & 5,80 & 5,90 & 5,90 & $5,87 \pm 0,06$ \\
\hline & 20 & 5,80 & 5,90 & 5,90 & $5,87 \pm 0,06$ \\
\hline & 25 & 5,80 & 5,90 & 5,90 & $5,87 \pm 0,06$ \\
\hline \multirow{6}{*}{$\mathrm{F} 2$} & - & 5,40 & 5,60 & 5,50 & $5,50 \pm 0,10$ \\
\hline & 5 & 5,50 & 5,70 & 5,70 & $5,60 \pm 0,11$ \\
\hline & 10 & 5,60 & 5,80 & 5,80 & $5,73 \pm 0,11$ \\
\hline & 15 & 5,70 & 5,90 & 5,90 & $5,83 \pm 0,11$ \\
\hline & 20 & 5,90 & 5,90 & 5,90 & $5,83 \pm 0,11$ \\
\hline & 25 & 5,90 & 5,90 & 5,90 & $5,83 \pm 0,11$ \\
\hline \multirow{6}{*}{$\mathrm{F} 3$} & - & 6,00 & 6,00 & 6,10 & $6,03 \pm 0,06$ \\
\hline & 5 & 6,10 & 6,10 & 6,20 & $6,13 \pm 0,06$ \\
\hline & 10 & 6,20 & 6,20 & 6,20 & $6,20 \pm 0,00$ \\
\hline & 15 & 6,30 & 6,40 & 6,40 & $6,37 \pm 0,06$ \\
\hline & 20 & 6,30 & 6,40 & 6,40 & $6,37 \pm 0,06$ \\
\hline & 25 & 6,30 & 6,40 & 6,40 & $6,37 \pm 0,06$ \\
\hline \multirow{6}{*}{$\mathrm{F} 4$} & - & 6,30 & 6,30 & 6,30 & $6,30 \pm 0,00$ \\
\hline & 5 & 6,40 & 6,50 & 6,50 & $6,47 \pm 0,06$ \\
\hline & 10 & 6,50 & 6,60 & 6,70 & $6,60 \pm 0,10$ \\
\hline & 15 & 6,70 & 6,70 & 6,80 & $6,73 \pm 0,06$ \\
\hline & 20 & 6,70 & 6,70 & 6,80 & $6,73 \pm 0,06$ \\
\hline & 25 & 6,70 & 6,70 & 6,80 & $6,73 \pm 0,06$ \\
\hline
\end{tabular}

\section{Hasil pemeriksaan karakteristik daya sebar}

Dari hasil pemeriksaan daya sebar pengaruh beban terhadap daya sebar masing-masing Formula pada beban konstan 25 gram dapat dilihat pada Tabel 3 dan Gambar 2, dihasilkan daya sebar F1 $<$ F2 $<$ F3 $<$ F4. 


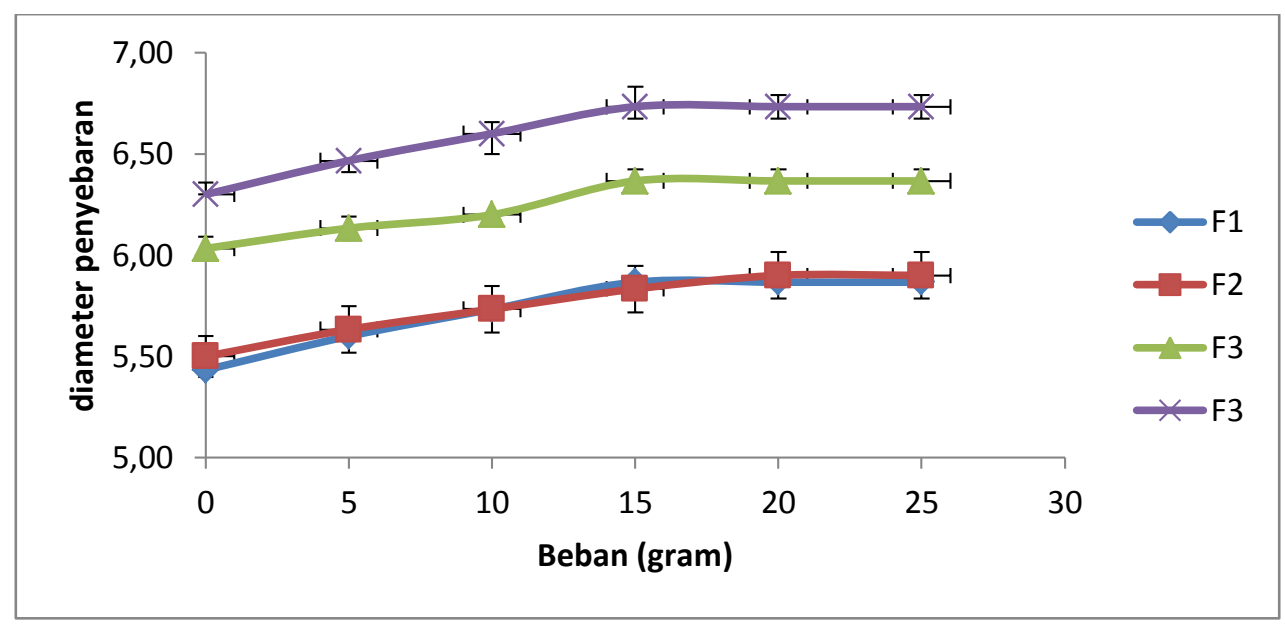

Gambar 2. Grafik profil karakteristik daya sebar dengan pengaruh penambahan beban pada formula 1 (F1), formula 2 (F2), formula 3 (F3), dan formula 4 (F4)

Selanjutnya dilakukan uji normalitas data, menunjukkan data tidak terdistribusi normal, sehingga dilanjutkan dengan uji statistika Kruskal Wallis. Berdasarkan uji statistik Kruskal Wallis diperoleh nilai $\mathrm{p}>0,05$ artinya tidak ada perbedaan bermakna daya sebar pada data yang berpasangan.

Berdasarkan data yang diperoleh tersebut menunjukkan penambahan SPACE peptide tidak memberikan peningkatan signifikan terhadap profil daya sebar. Daya sebar menjadi salah satu faktor penting dalam parameter acceptabilitas sediaan kosmetik.

\section{Hasil evaluasi stabilitas pH}

Hasil uji stabilitas dengan parameter $\mathrm{pH}$ dapat dilihat pada Tabel 4 dan Gambar 3. Hasil analisis statistik masing-masing Formula menggunakan metode Paired T-test menunjukkan bahwa semua formula tidak menunjukkan perbedaan nilai $\mathrm{pH}$ bermakna selama proses penyimpanan 21 hari. Sehingga dapat disimpulkan bahwa Formula 1, Formula 2, Formula 3, dan Formula 4 stabil secara fisika pada nilai pH. Nilai $\mathrm{pH}$ merupakan salah satu faktor yang penting diperhatikan terutama pada sampel yang mengandung growth factor, selain harus dijaga tetap sesuai dengan $\mathrm{pH}$ normal kulit agar tidak menimbulkan kekeringan dan iritasi, $\mathrm{pH}$ juga dapat mempengaruhi stabilitas dari growth factor. Growth factor yang merupakan salah satu protein ini dapat terdenaturasi dengan perubahan pH yang ekstrim (Kett dkk., 2004).

Tabel 4. Hasil pengukuran $\mathrm{pH}$ formula 1(F1), formula 2(F2), formula 3(F3), dan formula 4(F4) selama penyimpanan pada hari ke-0, ke-7, ke-14 dan ke-21

\begin{tabular}{clllll}
\hline Formula & Replikasi & Hari ke- 0 & Hari ke-7 & Hari ke-14 & Hari ke-21 \\
\hline \multirow{4}{*}{ F1 } & 1 & 5,48 & 54,3 & 5,43 & 5,44 \\
& 2 & 5,59 & 5,44 & 5,44 & 5,43 \\
& 3 & 5,70 & 5,73 & 5,73 & 5,74 \\
& Rata-rata \pm SD & $5,59 \pm 0,115$ & $5,53 \pm 0,171$ & $5,532 \pm 0,173$ & $5,527 \pm 0,172$ \\
\hline \multirow{4}{*}{ F2 } & 1 & 5,66 & 5,68 & 5,88 & 5,79 \\
& 2 & 5,82 & 5,82 & 5,85 & 5,88 \\
& 3 & 5,86 & 5,79 & 5,87 & 5,86 \\
& Rata-rata \pm SD & $5,78 \pm 0,106$ & $5.76 \pm 0,075$ & $5.87 \pm 0,014$ & $5,84 \pm 0,051$ \\
\hline \multirow{5}{*}{ F3 } & 1 & 5,87 & 5,90 & 6,13 & 6,14 \\
& 2 & 5,97 & 5,97 & 5,99 & 6,33 \\
& 3 & 6,15 & 5,98 & 6,20 & 6,22 \\
& Rata-rata \pm SD & $5,99 \pm 0,138$ & $5,95 \pm 0,014$ & $6,11 \pm 0,109$ & $6,23 \pm 0,095$ \\
\hline \multirow{5}{*}{ F4 } & 1 & 6,77 & 6,86 & 6,89 & 7,07 \\
& 2 & 6,70 & 6,76 & 6,76 & 7,50 \\
& 3 & 6,69 & 6,92 & 6,86 & 6,94 \\
& Rata-rata \pm SD & $6,71 \pm 0,043$ & $6,84 \pm 0,081$ & $6,836 \pm 0,069$ & $7,17 \pm 0,293$ \\
\hline
\end{tabular}




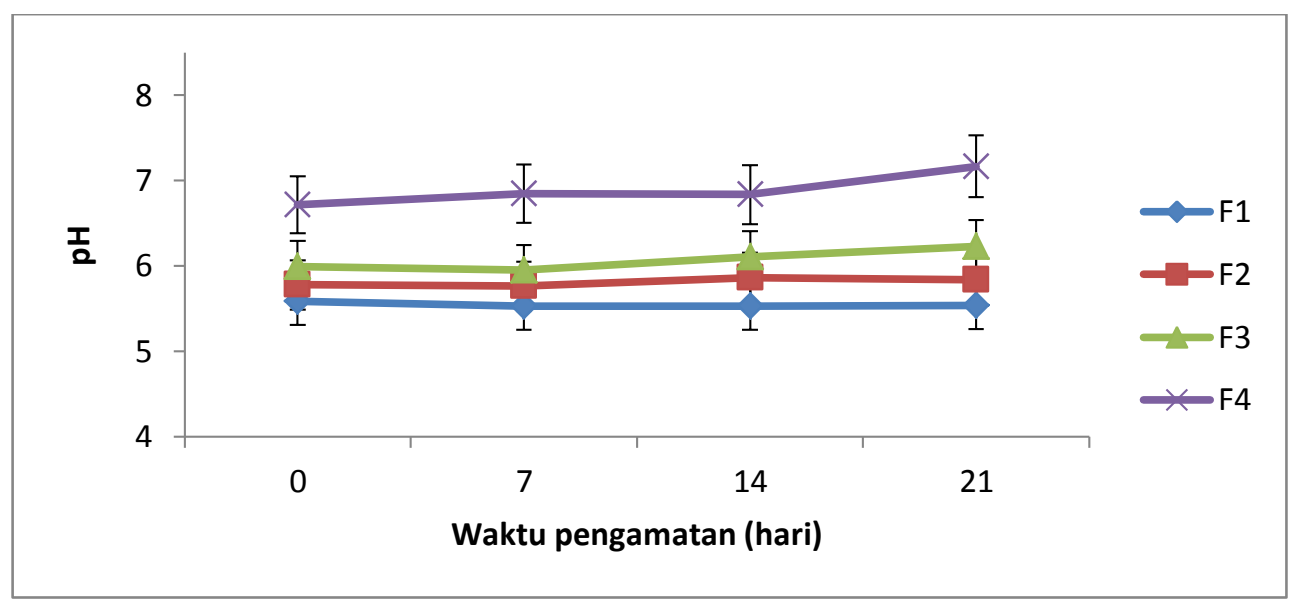

Gambar 3. Grafik profil pengamatan stabilitas $\mathrm{pH}$ selama waktu penyimpanan 21 hari

\section{Hasil evaluasi stabilitas daya sebar}

Hasil pengujian stabilitas daya sebar krim diamati setiap minggu selama selama 21 hari dapat dilihat pada Tabel 5 dan Gambar 4. Semua krim mengalami peningkatan daya sebar selama penyimpanan. Berdasarkan grafik pada Gambar 4 antara lama penyimpanan dan luas daya sebar dapat diamati bahwa F1 memiliki slope paling kecil dan F4 memiliki slope yang paling besar, artinya $\mathrm{F} 1$ memberikan kestabilan daya sebar yang lebih baik dibandingkan dengan F4. Sedangkan berdasarkan metode statistik Paired T-test menunjukkan nilai $\mathrm{p}>0,05$ berarti tidak ada perbedaan bermakna pada nilai daya sebar selama penyimpanan 21 hari. Sehingga disimpulkan bahwa semua formula stabil secara fisika pada nilai daya sebar.

Tabel 5. Hasil uji stabilitas daya sebar formula $1(\mathrm{~F} 1)$, formula 2(F2), formula 3(F3) dan formula $4(\mathrm{~F} 4)$ selama penyimpanan 21 hari

\begin{tabular}{ccccc}
\hline \multirow{2}{*}{ Formula } & \multicolumn{4}{c}{ Rata-rata diameter daya sebar $(\mathrm{cm}) \pm$ SD } \\
\cline { 2 - 5 } & Hari ke-0 & Hari ke-7 & Hari ke-14 & Hari ke-21 \\
\hline F1 & $5,90 \pm 0,00$ & $6,00 \pm 0,10$ & $6,13 \pm 0,06$ & $6,20 \pm 0,00$ \\
F2 & $5.87 \pm 0,06$ & $6,00 \pm 0,10$ & $6,20 \pm 0,00$ & $6,23 \pm 0,06$ \\
F3 & $6,37 \pm 0,06$ & $6,50 \pm 0,00$ & $6,83 \pm 0,06$ & $6,90 \pm 0,00$ \\
F4 & $6,73 \pm 0,06$ & $7,03 \pm 0,15$ & $7,17 \pm 0,12$ & $7,30 \pm 0,00$ \\
\hline
\end{tabular}

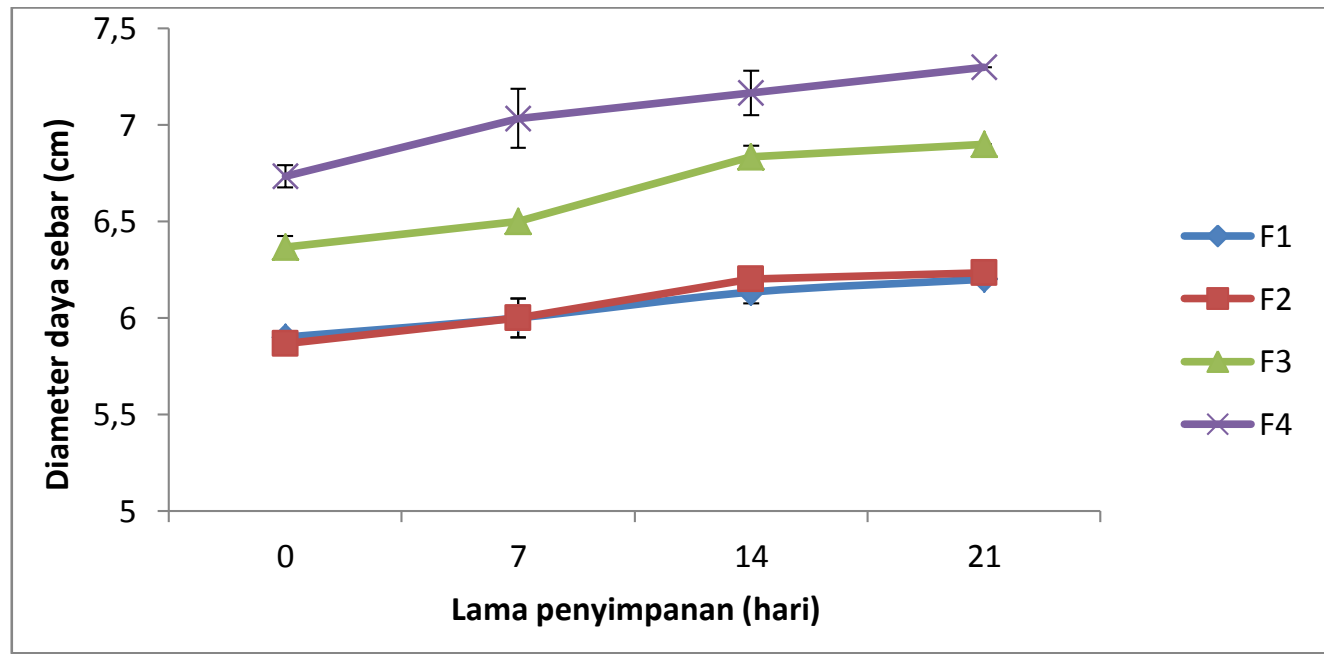

Gambar 4. Grafik Pengukuran stabilitas daya sebar pada penyimpanan selama 21 Hari Persamaan regresi linier:

$F 1: y=0,1033 x+5,80 ; R=0,9928 ; F 2: y=0,13 x+5,75 ; R=0,9705 ; F 3: y=0,1933 x+$ 6,$1667 ; R=0,9693 ; F 4: y=0,1833 x+6,6 ; R=0,9761$ 


\section{KESIMPULAN}

Penambahan variasi konsentrasi SPACE peptide terhadap masing-masing formula krim antiaging AMSC-MP tidak memberikan perbedeaan secara organoleptis. Pada pemeriksaan $\mathrm{pH}$, SPACE peptide meningkatkan $\mathrm{pH}$ sediaan, namun tidak berpengaruh terhadap daya sebar. Sementara pada pengujian stabilitas fisik menunjukkan bahwa semua Formula stabil selama penyimpanan 21 hari meliputi parameter stabilitas $\mathrm{pH}$ dan daya sebar.

\section{DAFTAR PUSTAKA}

Bos, J. D. \& Meinardi, M. M. H. M. (2000). The 500 Dalton Rule for the Skin Penetration of Chemical Compounds and Drugs. Experimental Dermatology; 9; 165-169.

Hsu, T. \& Mitragotri, S. (2011). Delivery of siRNA and Other Macromolecules Into Skin and Cells Using a Peptide Enhancer. Proceedings of the National Academy of Sciences of the United States of America; 108; 15816-15821.

Kett, V., McMahon, D. \& Ward, K. (2004). FreezeDrying of Protein Pharmaceuticals - the Application of Thermal Analysis. Cryo-Letters; 25; 389-404.

Kumar, S., Zakrewsky, M., Chen, M., Menegatti, S., Muraski, J. A. \& Mitragotri, S. (2015). Peptides as Skin Penetration Enhancers: Mechanisms of Action. Journal of Controlled Release; 199; 168-
178.

Lambers, H., Piessens, S., Bloem, A., Pronk, H. \& Finkel, P. (2006). Natural Skin Surface pH is on Average Below 5, Which is Beneficial for Its Resident Flora. International Journal of Cosmetic Science; 28; 359-370.

Lee, H. J., Kang, S., Lee, E. G. \& Sung, J. H. (2014). Efficacy of Microneedling Plus Human Stem Cell Conditioned Medium for Skin Rejuvenation: A Randomized, Controlled, Blinded Split-face Study. Annals of Dermatology; 26; 584-591.

Prakoeswo, C. R. S., Pratiwi, F. D., Herwanto, N., Citrashanty, I., Indramaya, D. M., Murtiastutik, D., Sukanto, H. \& Rantam, F. A. (2018). The Effects of Amniotic Membrane Stem CellConditioned Medium on Photoaging. Journal of Dermatological Treatment; 30; 478-482.

Seo, K. Y., Lee, S. E., Hyu, K. D. \& Yoon, M. S. (2013). Skin Rejuvenation by Microneedle Fractional Radiofrequency and a Human Stem Cell Conditioned Medium in Asian Skin: A Randomized Controlled Investigator Blinded Split-face Study. Journal of Cosmetic and Laser Therapy; $15 ; 25-33$.

Shin, J. W., Kwon, S. H., Choi, J. Y., Na, J. I., Huh, C. H., Choi, H. R., Park, K. C. (2019). Molecular Mechanisms of Dermal Aging and Antiaging Approaches. International Journal of Molecular Sciences; 20; 2126. 